\title{
Nursing Delirium Screening Scale, a Tool for Early Detection of Delirium: Integrative Review
}

Theme: Evidence-based practice

Contribution to the discipline: Knowing the different contexts in which the Nursing Delirium Screening Scale can be applicable provides nurses with an easy-to-use tool for the diagnosis of delirium and, thus, enables them to implement non-pharmacological interventions that contribute to its prevention and treatment. This instrument will allow nursing to be at the forefront of the management of this cognitive impairment.

\section{ABSTRACT}

Objective: To analyze the context and use of the Nursing Delirium Screening Scale (Nu-DESC) for early detection of delirium in adult patients, compiling the available evidence. Method: Searching for relevant articles on databases such as Cinahl, Medline, Ovid, Scopus, and Web of Science. Inclusion criteria: Articles written in English, Spanish, and Portuguese, published between January 2013 and October 2019. Search terms: "nursing delirium screen," "inpatient delirium screening," and "nursing assessment." We identified 23 articles in which the Nu-DESC was used. Two reviewers independently assessed the articles using the CASPe (Critical Appraisal Skills Program in Spanish) tool. Results: The Nu-DESC is employed in different contexts such as the adult intensive care unit (ICU), post-anesthetic care unit (PACU), palliative care unit, and hospitalization unit. It is more frequently used in the PACU with a more sensitive threshold $(\geq 1)$; the test showed greater sensitivity of $54.5 \%$ (95\% CI: 32.2-75.6) and specificity of 97.1\% (95\% CI: 95.3-98.4). Conclusion: The Nu-DESC facilitates the recognition of delirium episodes by the nursing team, makes care quicker and individualized for each patient, avoiding immediate pharmacological interventions, and coordinate interdisciplinary actions for diagnosis, especially in post-anesthetic care units.

\section{KEYWORDS (SOURce: DeCS)}

Delirium; Nu-DESC; screening; nursing; assessment; critical care; hospitalization; perioperative period.

\section{DOI: 10.5294/aqui.2020.20.4.5}

Para citar este artículo / To reference this article / Para citar este artigo Henao-Castaño AM, Pachón LE, Monroy JD. Nursing Delirium Screening Scale, a Tool for Early Detection of Delirium: Integrative Review. Aquichan. 2020;20(4):e2045. D0I: https://doi.org/10.5294/aqui.2020.20.4.5

\footnotetext{
$1 \bowtie$ https://orcid.org/0000-0003-4203-0016. Universidad Nacional de Colombia, Colombia. angmhenaocas@unal.edu.co

2 https://orcid.org/0000-0003-2708-8391. Universidad Nacional de Colombia, Colombia. laepachonce@unal.edu.co

3 https://orcid.org/0000-0002-6534-9102. Universidad Nacional de Colombia, Colombia.jdmonroyr@unal.edu.co
} 


\section{Nursing Delirium Screening Scale, una herramienta para la detección temprana del delírium: revisión integrativa}

\section{RESUMEN}

Objetivo: compilar la evidencia disponible con el fin de analizar el contexto y uso de la escala de detección del delírium para enfermería (Nu-DESC, por sus siglas en inglés) en la detección temprana del delírium en pacientes adultos. Método: búsqueda de artículos relevantes en bases de datos como Cinahl, Medline, Ovid, Scopus, Web of Science. Criterios de inclusión: artículos escritos en idioma inglés, español y portugués; publicaciones entre enero del 2013 y octubre del 2019. Los términos de búsqueda fueron: "nursing delirium screen", "inpatient delirium screening" y "nursing assessment". Se identificaron 23 artículos en los que se utilizó el instrumento Nu-DESC en diferentes contextos. Dos revisores de manera independiente realizaron la evaluación de los artículos utilizando la herramienta CASPe. Resultados: el uso de la Nu-DESC se presentó en diferentes contextos, tales como la unidad de cuidado intensivo adulto, la unidad de cuidado posanestésica, la unidad de cuidado paliativo y la unidad de hospitalización. En la unidad de cuidado posanestésico su uso es frecuente con un umbral más sensible en $\geq 1$; la prueba mostró una mayor sensibilidad del 54,5\% (IC del 95\%: 32,2-75,6) y una especificidad del 97,1\% (IC del $95 \%$ : 95,3-98,4). Conclusión: la Nu-DESC les permite a los enfermeros entrenados realizar el reconocimiento del evento de manera rápida y oportuna, individualizar el cuidado, lo que evita realizar intervenciones farmacológicas de manera inmediata, y coordinar acciones interdisciplinarias para el diagnóstico, en especial en unidades de cuidado postanestésico.

\section{PALABRAS CLAVE (Fuente: DeCS)}

Delírium; Nu-DESC; cribado; enfermería; evaluación; cuidado intensivo; hospitalización; periodo perioperatorio. 


\section{Nursing Delirium Screening Scale, uma ferramenta para detectar precocemente o delírio: revisão integrativa}

\section{RESUMO}

Objetivo: compilar a evidência disponível a fim de analisar o contexto e o uso da escala de deteç̧ão do delírio para enfermagem (Nu-Desc, por sua sigla em inglês) na detecção precoce do delírio em pacientes idosos. Método: busca de artigos relevantes em bases de dados como Cinahl, Medline, Ovid, Scopus, Web of Science. Critérios de inclusão: artigos em inglês, espanhol e português; publicações realizadas entre janeiro de 2013 e outubro de 2019. Os termos de busca foram: "nursing delirium screen", "inpatient delirium screening" e "nursing assessment". Foram identificados 23 artigos, nos quais foi utilizado o instrumento Nu-Desc em diferentes contextos. Dois revisores, de maneira independente, realizaram a avaliação dos artigos com o emprego da ferramenta Caspe. Resultados: a Nu-Desc foi utilizada em diferentes contextos, como a unidade de terapia intensiva de adultos, a unidade de recuperação pós-anestésica, a unidade de cuidado paliativo e a unidade de internação. Na de recuperação pós-anestésica, seu uso é frequente com uma faixa mais sensível em $\geq$ 1; 0 teste mostrou maior sensibilidade de 54,5\% (IC de $95 \%$ : 32,2-75,6) e especificidade de $97,1 \%$ (IC de $95 \%$ : 95,3-98,4). Conclusões: a Nu-Desc permite aos enfermeiros capacitados realizar o reconhecimento do evento de maneira rápida e oportuna, individualizar 0 cuidado, o que evita intervenções farmacológicas imediatas, e coordenar ações interdisciplinares para o diagnóstico, em especial em unidades de recuperação pós-anestésica.

\section{PALAVRAS-CHAVE (FonTE: DeCS)}

Delirium; delírio; Nu-DESC; peneiramento; enfermagem; avaliação. 


\section{Introduction}

Delirium is a disruption of consciousness characterized by inattention and cognitive/perception alterations developed in a short period (hours or days) and fluctuating over time (1). Within the perceptual-cognitive sphere, it is vital to recognize delirium in time, avoiding short- and long-term side effects. Therefore, monitoring is essential for its prompt identification and treatment (2).

Approximately $60-80 \%$ of all patients in intensive care units (ICU) develop this disorder. They may suffer other complications due to a lack of recognition, assessment, and treatment, hence the essential role nurses play in its identification and assessment for being by the patient's bedside. Early delirium detection facilitates treatment, minimizing its duration and possible side effects. In many hospitals, delirium detection is a standard procedure, but $72 \%$ of cases are not detected or are misdiagnosed. Some possible reasons for this are little time, knowledge of this condition, and unavailability of feasible and reliable instruments for diagnosis.

The Nursing Delirium Screening Scale (Nu-DESC) was developed and validated in a palliative care unit (3) for early detection of delirium; it consists of five items or categories. Its administration takes about two minutes and is accessible for clinical practice. It has been validated in different languages such as Danish (4), Turkish (5), Czech (6), and Korean (7), and used in different clinical practice scenarios: palliative care patients $(8,9)$, cardiac surgery $(10,11)$, liver transplantation (12), orthopedic surgery (13), urological surgery $(14,15)$, scheduled post-operative patients (16-19), post-anesthesia with medications such as ketamine (20), hospitalization (21), geriatrics hospitalization (22), oncologic hospitalization (23), and ICUs (24-26). The results of these studies report an average sensitivity of $96 \%$ and specificity of $81 \%$ using this scale.

The nurse must be able to carry out a complete and exhaustive evaluation to achieve an adequate clinical judgment; from the evidence-based practice, the nurse must help in the assessment using validated tools to measure and compare the patient's clinical evolution per shift. Delirium assessment tools include the Confusion Assessment Method for the ICU (CAM-ICU), the Intensive Care Delirium Screening Checklist (ICDSC), and the Nu-DESC, the latter being the most used by nurses. This article presents an analysis of the use of Nu-DESC, particularly in the ICU and postoperative care unit, to provide elements for the timely assessment of delirium by nurses.

\section{Method}

We conducted an integrative review applying the stages proposed by Ganong (27): identifying the topic and selecting the hypothesis or research question, establishing criteria for inclusion and exclusion of studies, sampling or searching in the literature, categorization of studies, interpreting and synthesizing the results. For this, the PICO (Problem, Intervention, Comparison, and Outcomes) strategy was used (14). The question that guided the intervention was, "What is the context of the application of the Nu-DESC for delirium detection?"

We searched for articles on online databases such as Cinahl, Medline, Ovid, Scopus, and Web of Science. The inclusion criteria were articles in English, Spanish, Portuguese, French, German, and Korean published between January 2013 and October 2019. The search terms were "nursing and delirium screen," "inpatient and delirium screening," and "hospitalized patients" (Figure 1).

Figure 1. Diagram of the process of searching for and selecting articles

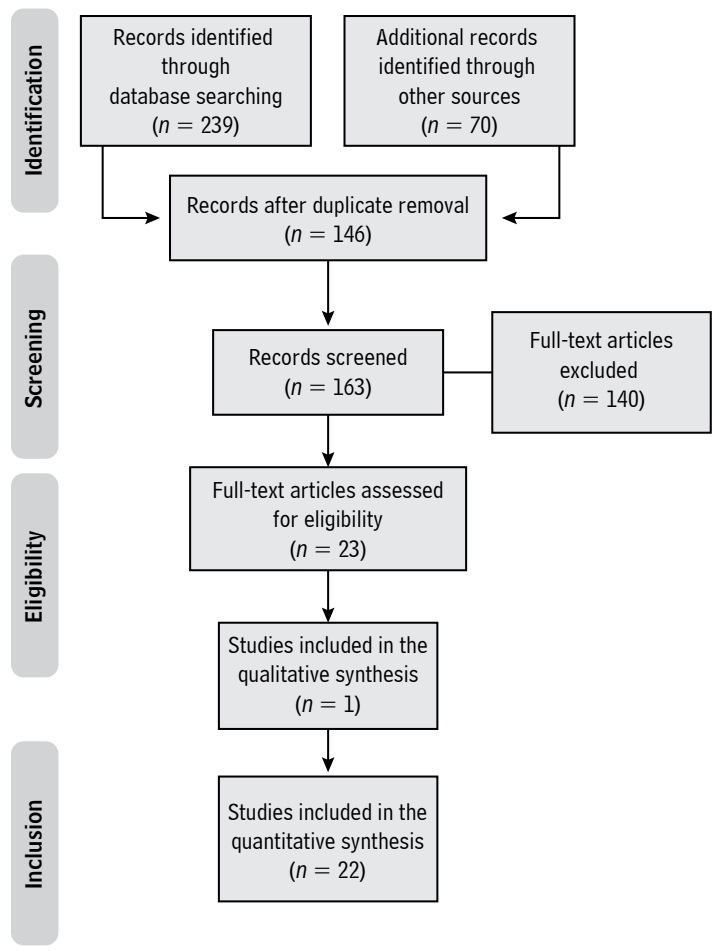

Source: Own elaboration based on (56). 
Two independent researchers first assessed all articles based on the title and abstract. If more information was needed, per the inclusion criteria, they read the whole article. To categorize the articles, two reviewers evaluated the studies included in the integrative review with the Critical Appraisal Skills Program templates in Spanish (CASPe) and then interpreted the results. Finally, the articles that met the inclusion and exclusion criteria (shown in Figure 2) were selected. The CASPe instrument was used for analysis and critical reading of the articles, which is fully available on the CASPe website (http://redcaspe.org).

We developed an instrument to collect data from the articles with information such as year of publication, authors, aim, coun- try, database, type of research, sampling details, intervention, results, and recommendations/conclusions. Then, they were categorized by topic, according to the interpretation of the outcomes and contributions to this review (Table 1).

\section{Results}

The Nu-DESC is an observational detection instrument composed of five items (orientation, behavior, communication, illusions/hallucinations, and psychomotor retardation). It has a sensitivity of $32-96 \%$ and specificity of $69-92 \%$ (28). After the integrative review, the categories obtained are utility of the Nu-DESC in the hospitalization unit, PACU, ICU, and palliative care unit.

Figure 2. Steps of the search methods and outcomes

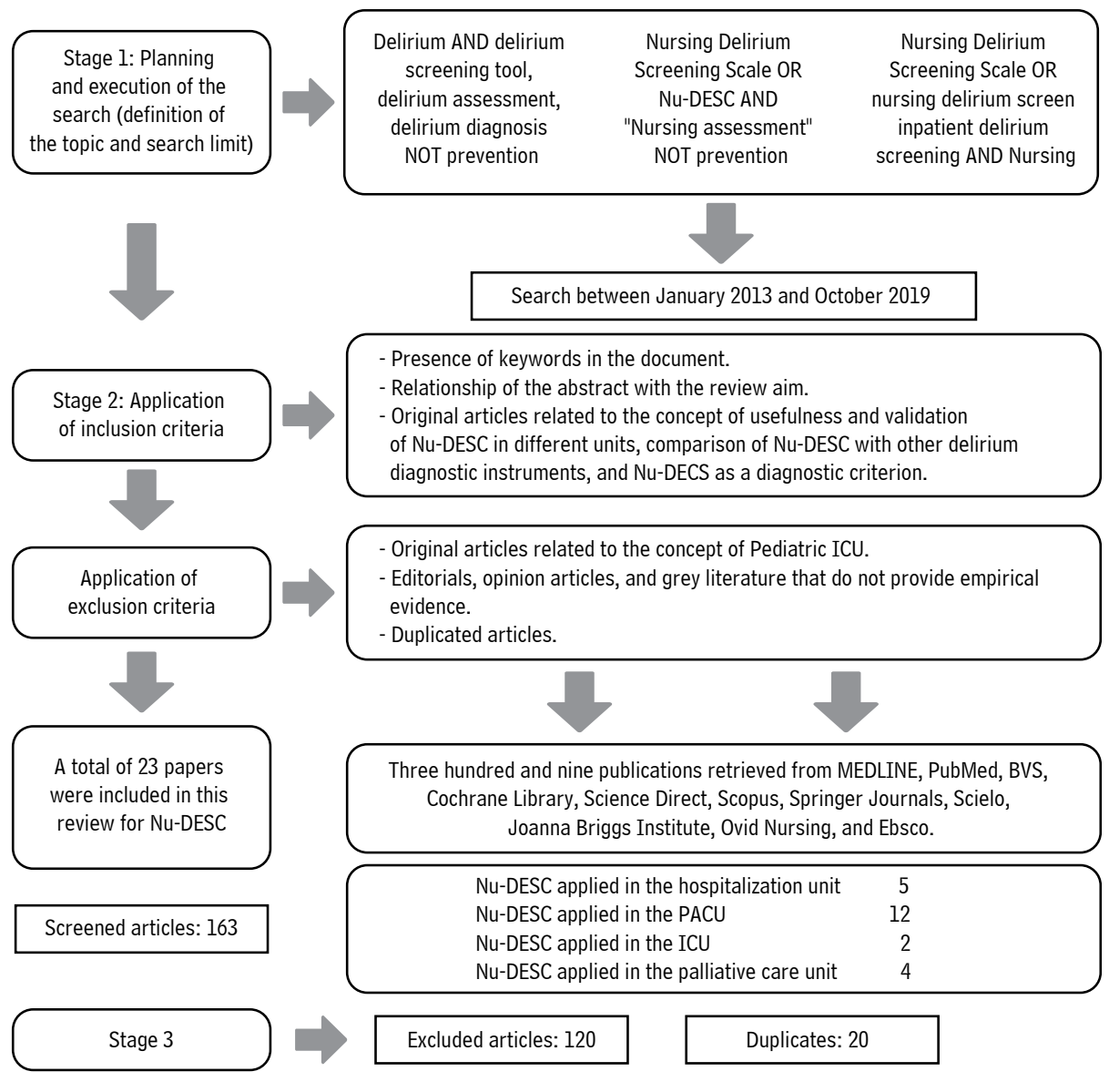

Source: Own elaboration. 
Table 1. Summary of selected articles

\begin{tabular}{|c|c|c|}
\hline Ref & Objective & Analysis of Results \\
\hline 29 & $\begin{array}{l}\text { To compare the validity of the Nu-DESC and Short-CAM in } \\
\text { general medical units and explore the impact of delirium } \\
\text { education on the successful implementation of delirium } \\
\text { screening tools }\end{array}$ & $\begin{array}{l}\text { The Nu-DESC proved to be an easy-to-use tool for } \\
\text { hospitalization services. }\end{array}$ \\
\hline 30 & $\begin{array}{l}\text { To compare phenotypes of diurnal fluctuation among different } \\
\text { delirium subtypes using a prospective design }\end{array}$ & $\begin{array}{l}\text { The Nu-DESC was used for diagnosing delirium in a liaison } \\
\text { consultation service by mental health nurses. }\end{array}$ \\
\hline 31 & $\begin{array}{l}\text { To validate the Nu-DESC under certain circumstances in } \\
\text { hospitalized patients }\end{array}$ & $\begin{array}{l}\text { The Nu-DESC exhibits good sensitivity and specificity in } \\
\text { hospitalized patients. }\end{array}$ \\
\hline 32 & $\begin{array}{l}\text { To validate the Nu-DESC in a German emergency } \\
\text { department (ED) }\end{array}$ & $\begin{array}{l}\text { The Nu-DESC showed good specificity but moderate sensitivity } \\
\text { when performed by nurses during their daily work in a } \\
\text { German hospital. }\end{array}$ \\
\hline 33 & $\begin{array}{l}\text { To translate the Nu-DESC and evaluate its performance in } \\
\text { Italian settings }\end{array}$ & $\begin{array}{l}\text { The Nu-DESC can be used in research and clinical practice } \\
\text { in Italian settings because of its outstanding performance, } \\
\text { similar to previous validation studies. }\end{array}$ \\
\hline 34 & $\begin{array}{l}\text { To validate the Portuguese version of the Nu-DESC for use in } \\
\text { critical care settings }\end{array}$ & $\begin{array}{l}\text { The Nu-DESC showed in its Portuguese version good } \\
\text { sensitivity and specificity for clinical use. }\end{array}$ \\
\hline 35 & $\begin{array}{l}\text { To validate the Swedish version of the Nu-DESC as a } \\
\text { screening tool }\end{array}$ & $\begin{array}{l}\text { The Nu-DESC was quickly incorporated into clinical care and } \\
\text { showed high sensitivity in detecting hyperactive symptoms of } \\
\text { delirium. }\end{array}$ \\
\hline 36 & $\begin{array}{l}\text { To evaluate the frequency, determining factors, and outcome } \\
\text { of inadequate delirium emergence after elective surgery in } \\
\text { the PACU }\end{array}$ & The Nu-DESC was used to diagnose post-operative delirium. \\
\hline 37 & $\begin{array}{l}\text { To determine the incidence of emerging delirium in adult } \\
\text { patients who had anesthesia with sevoflurane as the volatile } \\
\text { agent and the potential risk factors associated with its } \\
\text { occurrence }\end{array}$ & $\begin{array}{l}\text { The Nu-DESC was employed in the diagnosis of delirium in } \\
\text { patients under sevoflurane in the PACU. }\end{array}$ \\
\hline 38 & $\begin{array}{l}\text { To evaluate the performance of the } 4 A T \text { in the PACU in a } \\
\text { tertiary German medical center }\end{array}$ & $\begin{array}{l}\text { The Nu-DESC was used with the } 4 A T \text { to diagnose delirium } \\
\text { after anesthesia. }\end{array}$ \\
\hline 39 & $\begin{array}{l}\text { To evaluate the quality of recovery in elderly patients with } \\
\text { post-operative delirium (POD) }\end{array}$ & $\begin{array}{l}\text { The Nu-DESC was used for diagnosing delirium in the elderly } \\
\text { after anesthesia. }\end{array}$ \\
\hline 40 & To evaluate delirium screening tools in post-operative settings & $\begin{array}{l}\text { While highly specific, neither the CAM-ICU nor the Nu-DESC } \\
\text { (threshold } \geq 2 \text { ) is adequately sensitive to identify delirium } \\
\text { post-operatively; the Nu-DESC (threshold } \geq 1 \text { ) increases } \\
\text { sensitivity but reduces specificity. }\end{array}$ \\
\hline 41 & $\begin{array}{l}\text { To assess the agreement between the CAM-ICU and the } \\
\text { Nursing Delirium Screening Scale (NDSS) in the post-operative } \\
\text { period of cardiac surgery }\end{array}$ & $\begin{array}{l}\text { There was an agreement between the CAM-ICU and NDSS in } \\
\text { the post-operative period of cardiac surgery. }\end{array}$ \\
\hline
\end{tabular}




\begin{tabular}{|c|l|l|}
\hline Ref & \multicolumn{1}{|c|}{ Objective } & \multicolumn{1}{c|}{ Analysis of Results } \\
\hline 42 & $\begin{array}{l}\text { To compare three tools in assessing patients upon admission } \\
\text { to the recovery room in order to detect early signs of post- } \\
\text { operative brain dysfunction }\end{array}$ & $\begin{array}{l}\text { The Nu-DESC detected delirium in the first seven post- } \\
\text { operative days. }\end{array}$ \\
\hline 43 & $\begin{array}{l}\text { To test psychometrically the Finnish versions of the Neecham } \\
\text { Confusion Scale (NEECHAM) and the Nu-DESC in surgical } \\
\text { nursing care }\end{array}$ & The Nu-DESC was used to diagnose delirium in a surgical unit. \\
\hline 44 & $\begin{array}{l}\text { To evaluate patients' pupils and the Glasgow Coma Scale } \\
\text { (GCS) }\end{array}$ & $\begin{array}{l}\text { The Nu-DESC was used to detect neurological complications in } \\
\text { post-operative craniectomy. }\end{array}$ \\
\hline 45 & $\begin{array}{l}\text { To detect the presence of delirium using the Nu-DESC } \\
46\end{array}$ & $\begin{array}{l}\text { The Nu-DESC was used in the PACU by nursing personnel with } \\
\text { a low incidence. }\end{array}$ \\
\hline 47 & $\begin{array}{l}\text { To analyze POD in clinical practice after cardiac surgery, } \\
\text { how it is detected and documented, and whether the use of a } \\
\text { screening scale improves the detection rate }\end{array}$ & $\begin{array}{l}\text { The Portuguese Nu-DESC in post-operative patients with } \\
\text { previous alcohol consumption test showed } \geq 2 \text { in any of the } \\
\text { observations. }\end{array}$ \\
\hline 48 & $\begin{array}{l}\text { To determine the frequency and severity of symptom distress } \\
\text { and delirium }\end{array}$ & $\begin{array}{l}\text { The Nu-DESC is not a reliable tool for screening delirium when } \\
\text { a caregiver conducts the scoring. }\end{array}$ \\
\hline 49 & $\begin{array}{l}\text { To explore nurse perceptions of the feasibility of } \\
\text { integrating the Nu-DESC into practice within the inpatient } \\
\text { palliative care setting }\end{array}$ & $\begin{array}{l}\text { The Nu-DESC is feasible for use in a palliative care inpatient } \\
\text { setting but requires research on its psychometric properties } \\
\text { before routine use in this patient population. }\end{array}$ \\
\hline 50 & $\begin{array}{l}\text { To test the feasibility and acceptability of the delirium } \\
\text { measurement methodology }\end{array}$ & $\begin{array}{l}\text { The Nu-DESC and physician application of DSM-5 proved to be } \\
\text { feasible and acceptable in palliative care. }\end{array}$ \\
\hline
\end{tabular}

Source: Own elaboration.

\section{Nu-DESC and its use in Hospitalization}

Nu-DESC validation studies in multipurpose hospitalization units, where the incidence of delirium varies between 14.9-18.2\% and the mixed and hyperactive type prevails, demonstrate a moderate detection capacity with a sensitivity of $42-77.1 \%$ and specificity between $76-98 \%$ when the threshold is $>2$, compared to short-CAM whose sensitivity is $8.6-11.1 \%$ and specificity is $100 \%$. Also, it has optimal operational feasibility as it can be completed in approximately 2 minutes, which promotes the adherence of nursing professionals (approximately $90 \%$ ) to its use in the healthcare practice (29).
This measurement tool also responds to the characteristics of this pathology, such as fluctuation or severity of symptoms per type of presentation. This result is consistent with DSM-V criteria, as Kim et al. point out (30), identifying significant variations of symptoms in 244 hospitalized psychiatric patients when Nu-DESC scores showed that severe symptoms increased during the afternoon or at night. Patients with hyperactive and mixed type of delirium had higher scores in the disorientation, inappropriate behavior, and inappropriate communication items than patients with unspecified or hypoactive delirium. The difference between these types is a higher average score in psychomotor retardation and more significant fluctuations during the afternoon, while at night, the symptoms of hyperactive type intensified. Patients who 
had the hypoactive type had the highest average score in the psychomotor retardation item that differs from the unspecified type, whose fluctuations occur mostly during the day (30).

Concerning low diagnostic sensitivity, associated with the limited capacity to detect hypoactive delirium, a study was conducted in three hospitalization units with a sample of 405 patients (103 participants were admitted to neurology, 84 to general medicine, 82 to general surgery or orthopedics, and 136 to neurosurgery), 185 of which had delirium (11\% hypoactive type). It showed no statistical differences between the groups regarding age, sex, hospitalization unit, language, and post-operative state. This result indicates increased sensitivity ranging from $42 \%$ to $67 \%$ when the threshold is $>1$; however, specificity decreased from $98 \%$ to $93 \%$ (31).

Another exploratory analysis was conducted within a study of 315 patients admitted to an emergency unit for at least 12 hours, where the incidence of delirium was $14.9 \%$, with a predominance of the hypoactive type $(46.8 \%)$. It showed that the evaluation of item 1 (disorientation) combined with two elements of the Mini-Mental State Examination (MMSE) indicates that asking the patient the day of the week and name of the unit where he or she is located increases sensitivity from $66 \%$ to $77.8 \%$. This finding contrasts with the results obtained in the same study, where the disorientation item was not identified in 14 of 16 false positives cases (32). Although questions arise about the ability of $\mathrm{Nu}$-DESC to detect all forms of delirium, it is necessary to add the capacity to discriminate between delirium and differential diagnosis; Spendale et al. demonstrated it in a study of 101 patients hospitalized in different units where $79 \%$ of positive cases had a history of cognitive impairment (33).

\section{Nu-DESC and its use in the UCI}

Studies conducted in post-operative patients admitted to the ICU, where hypoactive type delirium predominates, show that Nu-DESC is a practical tool for delirium detection and has a sensitivity of $65.5-100 \%$ and specificity of $81.3-86 \%$. When considering the type of surgical intervention, a trend towards overestimating the incidence of Post-operative Delirium (POD) in patients undergoing non-cardiac or intracranial interventions was identified because of the number of false positives $(n=9)$ and positive predictive value (57\%). Abelha et al. (34) reported this in a study of 78 patients admitted to the ICU, where Nu-DESC performance was compared with the ICDSC as a gold standard.
When applying the Nu-DESC on days 1 to 4 of the post-operative period in patients undergoing scheduled cardiac surgery, the detection capacity decreases considerably from $65.6 \%$ (day 1 ) to $46.9 \%$ (day 4 ) when the threshold is $>2$. These results are associated with underestimation of hypoactive delirium that, due to its signs, unlike the hyperactive type, does not demand attention. However, it requires more monitoring for identification, accounting for the difference in diagnostic sensitivity between days 1 and 4 because on day one, the scale was applied in the ICU where the nurse-patient relationship was closer than in the general room, where it was applied on day 4.

Although changing care units implies diminution in suggestive sign detection (because of the fluctuating characteristics of delirium and the nurse/patient ratio), a change in the cognitive performance of patients is observed as the number of cases of delirium decreases on day $4(n=49)$, mostly with the hypoactive type $(n=28)$; the Nu-DESC detected just $50 \%(n=14)$ of those cases. Therefore, the evidence does not support that Nu-DESC detects the symptoms of hypoactive delirium optimally since there is a tendency to recognize the hyperactive type (35) mostly.

\section{Nu-DESC and its use in the PACU}

In adding all the articles reviewed in this area, approximately 1,500 patients were assessed for POD at different times: before surgery (where the Nu-DESC and MMSE were used to assess the pre-operative cognitive function (36)), ten minutes after extubation to verify ongoing delirium (37), upon admission to the PACU, upon discharge from the unit $(36,38)$, or up to 14 days after surgery (39). Previously, it was necessary to train the nursing staff in topics like delirium and application of the Nu-DESC (36). During the assessments, it was demonstrated that the execution time of the Nu-DESC does not take more than two minutes (40).

When making a detailed comparison with the CAM-ICU, it was found that its discriminatory characteristics are not better than this standard diagnostic criterion; therefore, it should not be replaced, despite low staff adherence due to difficulties in its application. However, the Nu-DESC showed a moderate agreement, according to the kappa coefficient (0.514) (41). At the same time, the results obtained by the Nu-DESC were compared or complemented with other scales such as the Richmond Agitation and Sedation Scale (RASS), the Post-Anesthetic Recovery Score (PARS), the Neelon and Champagne Confusion Scale (NEECHAM), the Ca- 
nadian Neurological Scale (CNS), the Bispectral Index (BIS), the Glasgow Coma Scale, (GCS) and the Ramsey Scale, showing high reliability in the Nu-DESC to detect POD (42-44).

POD was evaluated by the Nu-DESC in patients between 16 (45) and over 80 years old, finding that the most affected patients were older adults (> 65), especially those over 80 (39) who had ASA 3 or 4 in the pre-surgical period, while younger patients (with ASA 1 or 2) developed delirium in a smaller amount. Age influenced the incidence of delirium, which was between $4.3 \%$ (45) and $12.3 \%$ (39) in post-operative patients, who also had a more extended stay in the PACU (24\% vs. $10 \%)$ and hospitalization unit (7 vs. 4 days) compared to those who did not develop POD (46). Studies also showed that the Nu-DESC is highly effective in detecting hyperactive and mixed types, and moderately effective in the hypoactive type (47), with higher scores for disorientation and psychomotor retardation (43).

Regarding discriminatory capacities, a sensitivity between 69 $96 \%$ and specificity between $82-100 \%$ were reported (40). Neufeld et al. (40) and Saller et al. (38) found that the $>1$ threshold is more sensitive for the Nu-DESC (69\% (vs. 32\%) and 54.5\% (vs. 27\%), respectively). However, significant changes that affect specificity by decreasing it from $92 \%$ to $80 \%$ are also described (40).

One of the recommendations given by Smulter et al. (47) is to have better reports in clinical records about clinical findings in the PACU because, of all the patients who develop delirium in this unit, only $23 \%$ are diagnosed and $1 \%$ correctly identified and registered. The Nu-DESC also showed improvement in the recognition rate and allowed clinical staff to better record the findings (46).

\section{Nu-DESC and its use in the palliative care unit}

Despite the incidence and prevalence of delirium, particularly the hypoactive type, it is poorly recognized in patients who require palliative care or specialized care due to malignant tumor diagnosis. Clinical condition factors and patient's comorbidities, such as fatigue or depression, may make it challenging to recognize cognitive changes associated with delirium (48).

While multiple detection methods have been developed and validated, such as the Cognitive Rating Scale (CRS), Memorial Delirium Assessment Scale (MDAS), Confusion Assessment Method
(CAM), and Delirium Rating Scale-Revised-98 (DRS-R-98), these instruments are very complex to be applied or do not have adequate discriminatory power compared with the Nu-DESC. Although recent studies reported a lower discriminatory power when the threshold is $>2(63 \%)(48)$, the original study indicates that the Nu-DESC has greater sensitivity $(85.7 \%)$ when the threshold is $>1$. This result corroborates what was mentioned in the categories above and should be considered in subsequent studies (3).

Regarding the ability to detect hypoactive delirium (which is also related to our findings and the most underdiagnosed type), questions are raised about measuring the psychomotor delay, which can be linked or not as a symptom of delirium detected by health care personnel or caregivers. Many patients receive pharmacological treatment for symptom management, casting doubts about its application time, changing the outcome of the Nu-DESC (49), and increasing the number of false positives or false negatives as reported by Gaudreau et al. (3) (who associated severe analgesia as a factor that makes it difficult to establish a correct diagnosis). Besides, the findings of Hosie et al. (50) indicate an overestimation of the incidence of delirium by the Nu-DESC since only $19 \%$ of the evaluations were carried out on patients in the "stable" or "deteriorating" palliative care phases and terminal phase, following the DSM-V criteria.

\section{Discussion}

The use of Nu-DESC in different contexts such as the hospitalization unit, PACU, ICU, and palliative care unit facilitated the early diagnosis of delirium due to its easy application, considering that many of the studies were descriptive or comparative with other diagnostic scales.

The Nu-DESC, CAM-ICU, and DSM tools were the most used by nurses for detecting delirium in critical care units, post-operative units, especially older adults $(51,52)$. However, because of the lack of education in delirium recognition, nurses are not prepared to identify delirium in the unit. From their speeches, a strong relationship was observed with the lack of training, updating, and recycling on the subject to substantiate this conduct (53).

The role that nursing plays in the timely diagnosis of delirium through validated scales becomes increasingly valuable, knowing that delirium is a predictor of death in the patient, and the use of these tools allows for its timely recognition (54). 
The Nu-DESC is recognized for its easy application; it can be administered several times during the shift since the high workload and complexity of other scales are barriers to the timely diagnosis of delirium by nursing staff (55).

\section{Conclusions}

This review provides nurses with information and tools to assess delirium, especially in the ICU and PACU, at the time of discharge from the unit. Compared with other scales and individually, the Nu-DESC showed high sensitivity and specificity and is the most usable option for POD assessment, especially in the hyperactive and mixed subtypes. However, it does not replace CAMICU as a gold standard in delirium diagnosis.

In hospitalization units where education about delirium was given, we note that Nu-DESC is better at evaluating and helping to recognize and diagnose delirium than other scales, as contrasted with CAM-ICU, showing greater sensitivity and negative predictive value but lower specificity. We found no distinction of age or gender for a greater tendency to develop delirium. Nevertheless, a clinical history of a neurological or psychiatric disease does increase the prevalence of delirium.

The most recurrent subtype of delirium in hospitalized patients was the hyperactive one, backed by the identification of a high percentage of these cases by the Nu-DESC. Nevertheless, it is not very sensitive or specific to identify the development of the hypoactive subtype.

It is not possible to conclude that there is some relationship between taking one or more medications with the development of delirium during hospitalization.

We found that when the hyperactive or mixed subtypes were present, higher Nu-DESC scores were obtained.
We recommend evaluating the first item of the scale (disorientation) by asking the patient the current day of the week and the name of the unit where he/she is as it increases the sensitivity.

The implementation of the Nu-DESC in care, research, education, cancer prevention, and palliative care units demonstrates that it is a delirium detection tool with moderate discriminatory power and optimal operational feasibility (two minutes) compared to MDAS or CAM that are highly efficient in diagnosing. Nonetheless, it is more complex and presents difficulties when applied in patients with a fluctuating intensity of associated symptoms such as pain, fatigue, and nausea, among others, or impaired and terminal patients.

Therefore, Nu-DESC allows the trained nurse to recognize the event and individualize care, avoiding immediate pharmacological interventions, and coordinate interdisciplinary actions for delirium diagnosis and management involving family as the principal active caregiver.

\section{Limitations}

Articles in languages different from Spanish, English, or Portuguese were not included, neither the category of delirium in oncology patients.

\section{Implications for practice}

The literature reports the importance of early and routine detection of delirium in clinical practice. So, nurses need to know easy-to-use tools like the Nu-DESC scale, which is applicable in different hospital areas, to create a culture of prevention, detection, and management of delirium.

Conflict of interest: None declared. 


\section{References}

1. American Psychiatric Association. Diagnostic and Statistical Manual of Mental Disorders (DSM-IV-TR). 4th ed., Text Revision (DSM-IV-TR); 2000.

2. Slooter AJC, Van De Leur RR, Zaal IJ. Delirium in critically ill patients. In Handbook of Clinical Neurology. 1st ed. Vol. 141. Elsevier B.V.; 2017. p. 449-466. DOI: http://dx.doi.org/10.1016/B978-0-444-63599-0.00025-9

3. Gaudreau JD, Gagnon P, Harel F, Tremblay A, Roy MA. Fast, systematic, and continuous delirium assessment in hospitalized patients: The nursing delirium screening scale. J Pain Symptom Manage. 2005;29(4):368-75. DOI: http://dx.doi. org/10.1016/j.genhosppsych.2005.01.002

4. Hägi-Pedersen D, Thybo KH, Holgersen TH, Jensen JJ, Gaudreau JD, Radtke FM. Nu-DESC DK: The Danish version of the nursing delirium screening scale (nu-DESC). BMC Nurs. 2017;16(1):1-6. DOI: http://dx.doi.org/10.4040/ jkan.2012.42.3.414

5. Çlnar F, Eti Aslan F. Evaluation of Post-operative Delirium: Validity and Reliability of the Nursing Delirium Screening Scale in the Turkish Language. Dement Geriatr Cogn Dis Extra. 2019;9(3)362-73. DOI: http://dx.doi.org/10.1159/000501903

6. Ševčíková B, Kubešová HM, Šáteková L, Gurková E. Delirium screening instruments administered by nurses for hospitalized patients - Literature review. Cent Eur J Nurs Midwifery. 2019;10(4):1167-78. DOI: http://doi.org/10.15452/ CEJNM.2019.10.0028

7. Kim K-N, Kim C-H, Kim K-I, Yoo H-J, Park S-Y, Park Y-H. Development and validation of the Korean Nursing Delirium Scale. J Korean Acad Nurs. 2012;42(3):414. DOI: http://dx.doi.org/10.4040/jkan.2012.42.3.414

8. Tarot A, Van Lander A, Pereira B, Guastella V. To study the relation between distress and delirium of patients in palliative care. Med Palliat [Internet]. 2019;18(6):271-8. DOI: https://doi.org/10.1016/j.medpal.2019.01.003

9. Watanabe H, Matsunuma R, Suzuki K, Matsuda Y, Mori M, Yamaguchi T. The Current Practice of Oxygen Therapy for Dyspnea in Terminally Ill Cancer Patients: A Nationwide Survey of Japanese Palliative Care Physicians. J Pain Symptom Manage. 2019;58(4):e2-4. DOI: https://doi.org/10.1016/j.jpainsymman.2019.06.028

10. Noh EY, Park YH. Prevalence of delirium and risk factors in heart surgery patients in intensive care unit: A retrospective study. Korean J Adult Nurs. 2019;31(2):146-55. DOI: https://doi.org/10.7475/kjan.2019.31.2.146

11. John M, Ely EW, Halfkann D, Schoen J, Sedemund-Adib B, Klotz S, et al. Acetylcholinesterase and butyrylcholinesterase in cardiosurgical patients with post-operative delirium. J Intensive Care. 2017;5(1):1-10. DOI: https://doi.org/10.1186/ s40560-017-0224-1

12. Ri HS, Choi YJ, Park JY, Jin SJ, Lee YS, Son JM, et al. Elevation of Pre-operative Ammonia Level is not Associated with the Incidence of Post-operative Delirium in Patients with Liver Transplantation: A Propensity Score Matching Analysis. Transplant Proc [Internet]. 2020;52(1):219-26. DOI: https://doi.org/10.1016/j.transproceed.2019.11.012

13. Choi U, Kim SJ, Kang JS. Predictors for Incidence of Delirium after Musculoskeletal Operation in Elderly Patients. Korean J Stress Res. 2019;27(2):139-45. https://doi.org/10.17547/kjsr.2019.27.2.139

14. Becher KF. Das Delir bei geriatrischen Patienten in der Urologie. Urologe A. 2019;58(4):398-402. https://doi. org/10.1007/s00120-019-0887-4

15. Verdonk F. Le delirium postopératoire. Anesthésie \& Réanimation [Internet]. 2019;5(6):502-9. DOI: https://doi. org/10.1016/j.anrea.2019.09.005

16. Hernandez BA, Lindroth H, Rowley P, Boncyk C, Raz A, Gaskell A, et al. Post-anaesthesia care unit delirium: Incidence, risk factors and associated adverse outcomes. Br J Anaesth. 2017;119(2):288-90. https://doi.org/10.1093/bja/aex197

17. Radtke FM, Franck M, Schneider M, Luetz A, Seeling M, Heinz A, et al. Comparison of three scores to screen for delirium in the recovery room. Br J Anaesth. 2008;101(3):338-43. https://doi.org/10.1093/bja/aen193

18. Menzenbach J, Guttenthaler V, Kirfel A, Ricchiuto A, Neumann C, Adler L, et al. Estimating patients' risk for post-operative delirium from pre-operative routine data - Trial design of the PRe-Operative prediction of post-operative DElirium by appropriate SCreening (PROPDESC) study - A monocentre prospective observational trial. Contemp Clin Trials Commun. 2020;17. https://doi.org/10.1016/j.conctc.2019.100501 
19. Eertmans W, De Deyne C, Genbrugge C, Marcus B, Bouneb S, Beran M, et al. Association between post-operative delirium and post-operative cerebral oxygen desaturation in older patients after cardiac surgery. Br J Anaesth. 2020;124(2):14653. https://doi.org/10.1016/j.bja.2019.09.042

20. Riegger H, Hollinger A, Seifert B, Toft K, Blum A, Zehnder T, et al. Baden Prevention and Reduction of Incidence of Postoperative Delirium Trial (PRIDe): A phase IV multicenter, randomized, placebo-controlled, double-blind clinical trial of ketamine versus haloperidol for prevention of postoperative delirium. Trials. 2018;19(1):1-12. https://doi. org/10.1186/s13063-018-2498-6

21. Guihard N, Stefani L, Villard M, Mousseau M. Dépistage du syndrome confusionnel en soins palliatifs : étude prospective à l'aide de l'échelle Nu-Desc (Nursing Delirium Screening Scale) au centre hospitalier universitaire de Grenoble. Médecine Palliat. 2008;7(3):121-9. DOI: https://doi.org/10.1016/j.medpal.2007.10.004

22. Leung J, Reino M, Leung VC, Leung C, Unido MR, C FHK, et al. Clinical utility and validation of two instruments (the Algorithm Confusion Evaluation Method and the Chinese version of nursing delirium screening scale) to detect delirium in geriatric patients. Hosp Gen Psychiatry. 2008;30:171-6. DOI: https://doi.org/10.1016/j.genhosppsych.2007.12.007

23. Gaudreau JD, Gagnon P, Roy MA, Harel F, Tremblay A. Opioid medications and longitudinal risk of delirium in hospitalized cancer patients. Cancer. 2007;109(11):2365-73. DOI: https://doi.org/10.1002/cncr.22665

24. Luetz A, Heymann A, Radtke FM, Chenitir C, Neuhaus U, Nachtigall I, et al. Different assessment tools for intensive care unit delirium: Which score to use? Crit Care Med. 2010;38(2):409-18. DOI: http://doi.org/10.1097/CCM.0b013e3181cabb42

25. Morandi A, Brummel NE, Ely EW. Sedation, delirium and mechanical ventilation: the 'ABCDE' approach. Curr Opin Crit Care 2. 2011;17(1):43-9. DOI: https://doi.org/10.1097/mcc.0b013e3283427243

26. Schiemann A, Hadzidiakos D, Spies C. Erratum: Managing ICU delirium. Curr Opin Crit Care. 2011;17:131-40. DOI: https://doi.org/10.1097/MCC.0b013e32834400b5

27. Ganong LH. Integrative reviews of nursing research. Res Nurs Health. 1987;10(1):1-11. DOI: https://doi.org/10.1002/ nur.4770100103

28. Van Velthuijsen EL, Zwakhalen SMG, Warnier RMJ, Mulder WJ, Verhey FRJ, Kempen GIJM. Psychometric properties and feasibility of instruments for the detection of delirium in older hospitalized patients: a systematic review. Int J Geriatr Psychiatry. 2016;31(9):974-89.DOI: https://doi.org/10.1002/gps.4441

29. Heinrich TW, Kato H, Emanuel C, Denson S. Improving the Validity of Nurse-Based Delirium Screening: A Head-to-Head Comparison of Nursing Delirium-Screening Scale and Short Confusion Assessment Method. Psychosomatics [Internet]. 2019;60(2):172-8. DOI: https://doi.org/10.1016/j.psym.2018.09.002

30. Kim SY, Kim JM, Kim SW, Kim ES, Kang HJ, Lee JY, et al. Do the Phenotypes of Symptom Fluctuation Differ Among Motor Subtypes in Patients With Delirium? J Pain Symptom Manage [Internet]. 2018;56(5):667-77. DOI: https://doi. org/10.1016/j.jpainsymman.2018.07.022

31. Hargrave A, Bastiaens J, Bourgeois JA, Neuhaus J, Josephson SA, Chinn J, et al. Validation of a Nurse-Based Delirium-Screening Tool for Hospitalized Patients. Psychosomatics [Internet]. 2017;58(6):594-603. DOI: http://dx.doi. org/10.1016/j.psym.2017.05.005

32. Grossmann FF, Hasemann W, Nickel CH. Detecting delirium in elderly medical emergency patients: validation and subsequent modification of the German nursing delirium screening scale-comment. In: Internal and Emergency Medicine. Vol. 14; 2019. p. 1009. DOI: https://doi.org/10.1007/s11739-018-1989-5

33. Spedale V, Di Mauro S, Del Giorno G, Barilaro M, Villa CE, Gaudreau JD, et al. Delirium assessment in hospitalized elderly patients: Italian translation and validation of the nursing delirium screening scale. Aging Clin Exp Res. 2017;29(4):67583.DOI: https://doi.org/10.1007/s40520-016-0621-7

34. Abelha F, Veiga D, Norton M, Santos C, Gaudreau JD. Delirium assessment in post-operative patients: Validation of the Portuguese version of the Nursing Delirium Screening Scale in critical care. Brazilian J Anesthesiol [Internet]. 2013;63(6):450-5. DOI: http://dx.doi.org/10.1016/j.bjane.2012.09.003

35. Lingehall HC, Smulter N, Engström KG, Gustafson Y, Olofsson B. Validation of the Swedish version of the Nursing Delirium Screening Scale used in patients 70 years and older undergoing cardiac surgery. J Clin Nurs. 2013 Oct;22(1920):2858-66. DOI: https://doi.org/10.1111/j.1365-2702.2012.04102.x 
36. Xará D, Silva A, Mendonça J, Abelha F. Inadequate emergence after anesthesia: Emergence delirium and hypoactive emergence in the Postanesthesia Care Unit. J Clin Anesth. 2013 Sep 1;25(6);439-46. DOI: https://doi.org/10.1016/j. jclinane.2013.02.011

37. Ramroop R, Hariharan S CD. Emergence delirium following sevoflurane anesthesia in adults: prospective observational study. Brazilian J Anesthesiol. 2019;69(3):233-41. DOI: https://doi.org/10.1016/j.bjane.2018.12.012

38. Saller T, MacLullich AMJ, Schäfer ST, Crispin A, Neitzert R, Schüle C, et al. Screening for delirium after surgery: validation of the 4 A's test (4AT) in the post-anaesthesia care unit. Anaesthesia. 2019;74(10):1260-6. DOI: https://doi. org/10.1111/anae.14682

39. Cristelo D, Ferreira MN, Castro JSE, Teles AR, Campos MAF. Quality of recovery in elderly patients with postoperative delirium. Saudi J Anesth. 2019;13(4):285-289. DOI: https://doi.org/10.4103/sja.SJA_747_18

40. Neufeld KJ, Leoutsakos JS, Sieber FE, Joshi D, Wanamaker BL, Rios-Robles J, et al. Evaluation of two delirium screening tools for detecting post-operative delirium in the elderly. Br J Anaesth. 2013;111(4):612-8. DOI: https://doi.org/10.1093/ bja/aet 167

41. Alcoba Pérez T, Ciria Poza S, Carracedo Catalán C, García Fernández A, Marcos Vidal JM. Valoración de la concordancia entre la escala CAM-ICU y la nursing delirium screening scale en el postoperatorio de cirugía cardiaca en una unidad de críticos. Enferm Intensiva [Internet]. 2014;25(3):100-6. DOI: http://dx.doi.org/10.1016/j.enfi.2014.03.003

42. Stukenberg S, Franck M, Spies CD, Neuner B, Myers I, Radtke FM. How can post-operative delirium be predicted in advance? A secondary analysis comparing three methods of early assessment in elderly patients. Minerva Anestesiol. 2016;82(7):751-9. Available from: https://pubmed.ncbi.nlm.nih.gov/27453295/

43. Poikajärvi S, Salanterä S, Katajisto J, Junttila K. Validation of Finnish Neecham Confusion Scale and Nursing Delirium Screening Scale using Confusion Assessment Method algorithm as a comparison scale. BMC Nurs. 2017;16(1):1-11. DOI: https://doi.org/10.1186/s12912-016-0199-6

44. Herrero S, Carrero E, Valero R, Rios J, Fábregas N. Monitoramento de pacientes neurocirúrgicos no pósロoperatório utilidade dos escores de avaliação neurológica e do índice bispectral. Brazilian J Anesthesiol. 2017 Mar 1;67(2):153-65. DOI: https://doi.org/10.1016/j.bjan.2016.12.001

45. Winter A, Steurer MP, Dullenkopf A. Post-operative delirium assessed by post anesthesia care unit staff utilizing the Nursing Delirium Screening Scale: A prospective observational study of 1000 patients in a single Swiss institution. BMC Anesthesiol [Internet]. 2015;15(1):1-6. DOI: http://dx.doi.org/10.1186/s12871-015-0168-8

46. Sousa G, Pinho C, Santos A, Abelha FJ. Delirio postoperatorio en pacientes con historial de abuso de alcohol. Rev Esp Anestesiol Reanim [Internet]. 2017;64(4):214-22. DOI: http://dx.doi.org/10.1016/j.redar.2016.07.009

47. Smulter N, Claesson Lingehall H, Gustafson Y, Olofsson B, Engström KG. The use of a screening scale improves the recognition of delirium in older patients after cardiac surgery-A retrospective observational study. J Clin Nurs. 2019;28(11-12):2309-18. DOI: https://doi.org/10.1111/jocn.14838

48. De La Cruz M, Noguera A, San Miguel-Arregui MT, Williams J, Chisholm G, Bruera E. Delirium, agitation, and symptom distress within the final seven days of life among cancer patients receiving hospice care. Palliat Support Care. 2015;13(2):211-6. DOI: https://doi.org/10.1016/j.psym.2018.09.002

49. Hosie A, Lobb E, Agar M, Davidson PM, Chye R, Phillips J. Nurse perceptions of the Nursing Delirium Screening Scale in two palliative care inpatient units: A focus group study. J Clin Nurs. 2015;24(21-22):3276-85. DOI: https://doi. org/10.1111/jocn.12925

50. Hosie A, Lobb E, Agar M, Davidson P, Chye R, Lam L, et al. Measuring delirium point-prevalence in two Australian palliative care inpatient units. Int J Palliat Nurs. 2016;22(1):13-21. DOI: https://doi.org/10.12968/ijpn.2016.22.1.13

51. Powell TL, Nolan M, Yang G, Tam M, Metter D, Gibran NS, et al. Nursing Understanding and Perceptions of Delirium: Assessing Current Knowledge, Attitudes, and Beliefs in a Burn ICU. J Burn Care Res. 2019;40(4):471-7. DOI: https://doi. org/10.1093/jbcr/irz040

52. Saller T, Hofmann-Kiefer KF, Saller I, Zwissler B, von Dossow V. Implementation of strategies to prevent and treat post-operative delirium in the post-anesthesia caring unit: A German survey of current practice. J Clin Monit Comput [Internet]. 2020;(0123456789). DOI: https://doi.org/10.1007/s10877-020-00516-9 
53. Gomes de Oliveira Tostes IC, Pereira SRM, De Almeida LF, Dos Santos MM. Delirium em terapia intensiva: utilização do Confusion Assessment Method for the Intensive Care Unit pelo enfermeiro. Rev Pesqui Cuid é Fundam Online. 2018;10(1):2. DOI: https://doi.org/10.9789/2175-5361.2018.v10i1.2-8

54. Mansouri P, Javadpour S, Zand F, Ghodsbin F, Sabetian G, Masjedi M, et al. Implementation of a protocol for integrated management of pain, agitation, and delirium can improve clinical outcomes in the intensive care unit: A randomized clinical trial. J Crit Care [Internet]. 2013;28(6):918-22. Available from: http://dx.doi.org/10.1016/j.jcrc.2013.06.019

55. Velásquez Gaviria LM. Instruments for the diagnosis of delirium in Spanish speakers: a review article. Med UPB. 2016;35(2):100-10. DOI: https://doi.org/10.18566/medupb.v35n2.a04

56. Moher D, Liberati A, Tetzlaff J, Altman DG; PRISMA Group. Preferred reporting items for systematic reviews and meta-analyses: the PRISMA statement. PLoS Med. 2009 Jul 21;6(7):e1000097. DOI: https://doi.org/10.1371/journal. pmed.1000097 